\title{
Factors influencing job satisfaction among academic staffs
}

\author{
Ong Choon Hee, Chong Hui Shi, Tan Owee Kowang, Goh Chin Fei, Lim Lee Ping \\ Azman Hashim International Business School, Universiti Teknologi Malaysia, Malaysia
}

\begin{tabular}{l}
\hline \hline Article Info \\
\hline Article history: \\
Received Feb 4, 2020 \\
Revised Mar 17, 2020 \\
Accepted Apr 30, 2020 \\
\hline
\end{tabular}

\section{Keywords:}

Job satisfaction

Pay and benefits

Top management leadership

Work environment

Workload

\begin{abstract}
The purpose of this study is to examine the relationship between pay and benefits, work environment, top management leadership, workload and job satisfaction among academic staffs in a private academic institution in Malaysia. Motivation-Hygiene Theory, Maslow's Needs Hierarchy theory and Leader-Member Exchange (LMX) theory were used to establish the theoretical framework of this study. Questionnaire survey method was employed to collect data which yielded 82 responses in this study. Statistical Package for Social Science (SPSS) was used to perform data analysis throughout the study. All study variables were found to have significant positive relationships with job satisfaction among academic staffs in the selected institution. Top management leadership was discovered to have the most significant relationship with job satisfaction. The findings of this research provide a clear message to the top management that leadership plays an important role in enhancing job satisfaction of the academic staffs. Hence, it is suggested that the institution management should adopt appropriate leadership style and establish effective strategies and policies that aim to increase job satisfaction and performance of the academic staffs.
\end{abstract}

This is an open access article under the CC BY-SA license.

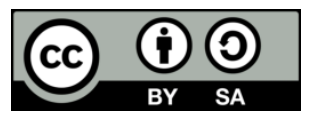

\section{Corresponding Author:}

Ong Choon Hee,

Azman Hashim International Business School,

Universiti Teknologi Malaysia,

Johor Bahru, 81310, Malaysia.

Email: ongchoonhee@gmail.com

\section{INTRODUCTION}

Over the years, job satisfaction has been a general topic in many countries around the world. An individual's job performance is generally depends on his or her job satisfaction level. One's organizational performance will increase if the employee job satisfaction level is high. Referring to researchers [1], individuals who are pleased with their current works incline to be more motivated and willing to exert more efforts in performing their duties. Job satisfaction is able to influence employees' attitude, loyalty, support and dedication towards the organization. There were many studies about job satisfaction globally and in various sectors such as banking, construction, manufacturing, hotels, transportation and etc. However, this paper concentrates on education sector. Education is a crucial sector in developing a country. It undeniable that education is vital for our future generation. Therefore, education system of a nation must be well established so that it could to deliver desired results and produce high quality of education. According to researchers [2], academic staffs were involved in determining the quality of education and play important roles in one's country educational development. If academic staffs are unhappy with their works, it will directly affect the output of their works [2]. Thus, it is essential to measure job satisfaction level of the academic staffs and determine significant factors that associated with their job satisfaction. In this research, the authors have selected a private academic institution in Malaysia to to explore determinants that enable private colleges to achieve greater ratings in the Malaysian Quality 
Evaluation System for Private Colleges (MyQUEST). As suggested by researchers [3], opportunity for promotion, salary, work environment, workload, relationship with staffs, style of administration were among the factors that influenced academic staffs' job satisfaction. By using Motivation-Hygiene Theory, Maslow's Needs Hierarchy Theory, and Leader-Member Exchange (LMX), few factors (i.e. pay and benefits, work environment, top management leadership, workload) have been chosen to establish the theoretical framework in predicting job satisfaction.

\section{LITERATURE REVIEW AND HYPOTHESIS DEVELOPMENT}

\subsection{Job satisfaction}

Job satisfaction is a significant subject for every organization in various industries. Many organizations or superiors wanted to know whether their workers or subordinates are contented with their jobs. Job satisfaction is understood as accomplishment of tasks by enployees who obtain sense of achievement from their workplace [4]. Researchers have explained job satisfaction as the good feeling one gets when one has a job he or she enjoys doing it [5]. Job satisfaction is also a constructive emotional domain derived from the personal opinions of the employees about their work. Basically, it is measuring how a person finds his task and how far he is able to perform the task. According to researchers [3], they mentioned that job satisfaction is a feeling about the career of an individual or about specific aspects of the job that will impact productivity and job performance of an organization. Job satisfaction is an internal feeling of a worker about his job [6]. Job satisfaction is also a psychological response of a work situation [5]. Academic staffs' job satisfaction is vital as it is a foundation of inspiration that needed for continuous effort in accomplishing the tasks required for a good teacher. The works that academic staffs need to perform are preparing lectures notes, day-to-day lesson plan, marking of assignments as well as to keep track and monitor students' progress and their performance. Apart from performing all these tasks, academic staffs will also have to keep themselves updated with current knowledge and educational development. Academic staffs are likely to act as a counsellor and role model to students. Therefore, job satisfaction is crucial for academic staffs as it will positively impact their job performance in educating, developing and shaping future leaders.

\subsection{Pay and benefits}

Pay and benefits are common financial incentives [7]. Benefits are generally defined as nonmonetary compensation [8]. Pay and benefits are essential elements that used to motivate employees in the organization. It helps to increase workers' performance and productivity. A research done by researcher [9] reported that basic salaries and allowances affects academic staffs' job satisfaction. The finding shows that pay and benefits are significantly related to job satisfaction. The finding is in line with the research of Dulebohn's [10]. It was discovered that salary not only allows individuals to meet their fundamental needs but provides job satisfaction at a higher level as well. Researcher [11] also found that on top of pay and allowances, fringe benefits also influence one's job satisfaction. On the same note, Researcher [12] confirmed that rewards and benefits are significantly associated with job satisfaction. However, poor compensation and benefits will have negative impacts on job satisfaction [13]. Therefore, it is hypothesized: H1: Pay and benefits have a significant relationship with job satisfaction.

\subsection{Work environment}

Work environment is explained as the setting, situation and environment in which people work [14]. It is also referred to the environment where it comprises people, tools, and other workplace physical components [14]. According to researcher [15], work environment is explained as a place where people work together to complete tasks and achieve common goals. Researcher [9] discovered that academic staff's job satisfaction is related to work environemnt. Similarly, researchers [16] echoed that good work environment contributes towards academic staffs' job satisfaction regardless of types of schools, colleges and demographics. Likewise, researchers [6, 17] emphasized that supportive working condition improves academic staffs' job satisfaction. Hence, the following hypothesis is proposed:

$\mathrm{H} 2$ : Work environment has a significant relationship with job satisfaction.

\subsection{Top management leadership}

Top management is referred to a group of individuals at the top level who are managing an organization [18]. Top management leadership is seen as a social communicating process between the leader and his followers. Generally, leaders influence the achievement of an organization's goals via change, innovation, engagement and motivational activities [19, 20]. According to researchers [21], top management's leadership style is important in influencing academic staffs' job satisfaction. Top management is responsible to improve academic staffs' job satisfaction. Research study done by [21] stated that if top 
management provides positive feedback, it will have positive impact towards academic staffs' job satisfaction. Top management's capability to allocate work equally has direct effect on job satisfaction as well. The study implies that principal leadership or top management leadership is one of the significant determinants in predicting teachers and academic staffs' job satisfaction and it also proved that academic staffs who work with supportive top management have higher job satisfaction [21]. Therefore, it is hypothesized that:

H3: Top Management leadership has a significant relationship with job satisfaction.

\subsection{Workload}

Workload is defined as the number of tasks given to an individual over a specified period of time [22]. Workload is generally referred to the intensity of the job assignments [23]. Researchers [24] mentioned that heavy workload and tremendous administrative work will cause job dissatisfaction among academic staffs. The work itself may also contribute towards job satisfaction. The study of [25] stated that lower workload will increase job satisfaction level among academic staffs. In another study of [21], they argued that tremendous workload would have negatively influenced academic staffs' performance and job satisfaction.; the lower the workload, the higher the job satisfaction. On the contrary, increasing the workload of academic staffs will result in low efficiency and job dissatisfaction. Therefore, it is hypothesized that: H4: Workload has a significant relationship with job satisfaction.

\section{RESEARCH METHOD}

\subsection{Population and sample}

The purpose of this research study is to explore factors that influence job satisfaction among academic staffs in a private academic institution in Malaysia. The total population of the institution consists of 100 academic staffs who are employed by this private college. Based on the sampling table by researchers [26], the desired sample size required for a population of 100 is 80 . Simple random sampling method was employed to draw the respondents from the population. The researcher has successfully collected 82 responses from the respondents.

\subsection{Measures}

The measurement items of job satisfaction (8 items) were adapted from the studies of [27, 28]. The aim of these measures is to provide the opportunity for academic staffs to feedback their feelings and indicate the level of agreement whether they are satisfied or dissatisfied with their works. In this research, there are four predictor constructs to be measured, namely pay and benefits, work environment, top management leadership and workload. The measures of pay and benefits (6 items) were selected and modified from researcher [29], while the items of work environment (5 items) were adapted from [27]. Measures for top management leadership (6 items) and workload (5 items) were adapted from [30, 31] respectively. A 5-point Likert scale was utilized to measure all the study variables.

\subsection{Data collection procedure}

Data collection was conducted by using self-administered questionnaire. The questionnaire was prepared in English to best convey the contents to the respondents. The researcher personally administered the survey questionnaires. The completed questionnaires were collected one day after the respondents received the questionnaires. The questions were divided into three categories that consist of demographic profile, job satisfaction, and determinants of job satisfaction (i.e. pay and benefits, work environment, top management leadership and workload). In this study, validity and reliability test, correlation and multiple regression analysis were employed for data analysis. We use Statistical Package for Social Sciences (SPSS) for data analysis.

\section{RESULTS AND DISCUSSION}

\subsection{Profile of the respondents}

Based on the 82 responses were generated, 29 of the respondents were males and constituted $35.4 \%$ of the total respondents, while the rest of them $(53,64.6 \%)$ were females. Most of the participants were aged between 24 to 35 years old and formed $50 \%$ of the total respondents. In the categories of ethnicity, most of the respondents were Chinese $(56,68.3 \%)$, followed by Indian $(19,23.2 \%)$ and Malay $(7,8.5 \%)$. In the category of academic qualification, 23 (28\%) respondents were bachelor's degree holders, followed by 56 and 3 of the respondents were master's degree and doctoral degree holders respectively. Majority of the participants $(31,37.8 \%)$ were having 6-10 years of work experience while 30 respondents $(36.6 \%)$ were 
categorized between 1-5 years of length of service. Other respondents were ranging from less than 1 year of work experience $(6,7.3 \%), 11-15$ years $(13,15.9 \%), 16-20$ years $(1,1.2 \%)$ and above 20 years $(1,1.2 \%)$.

\subsection{Factor analysis}

In this research, there are four predictor constructs namely pay and benefits, work environment, top management leadership and workload. Validity test was conducted by using factor analysis with Principal Component Analysis (PCA). Bartlett's Test of Sphericity was used to test the construct valideity. The KMO/MSA values indicate the strength among the constructs. Workload was eliminated during Principal Component Analysis (PCA) owing to cross laodings. As shown in Table 1, the results indicated that the value of KMO/MSA is 0.823 for the predictor constructs. According to [32], values of KMO/MSA above 0.8 are suitable for factor analysis. The Bartlett's test of Sphericity supported the factor analysis with $\mathrm{p}<0.001$. The results of the factor analysis disclosed that there are 3 factors extracted. All factor loadings were above 0.50 and in the range of 0.741 to 0.894 . Factor 1 is referred to top management leadership (6 items) whereas factor 2 is identified as pay and benefits (4 items) and finally factor 3 is recognized as work environment ( 2 items). According to the analysis results, the percentages of variance explained for top management leadership, pay and benefits and work environment are $35.906 \%, 25.622 \%$ and $15.282 \%$ and recorded $76.810 \%$ of the cumulative variance. The Eigenvalues (i.e. $6.133,1.870$ and 1.214) for the factors were above one thus supporting the factor loading results.

Table 1. Factor analysis for the independent variables

\begin{tabular}{|c|c|c|c|c|}
\hline \multirow{2}{*}{ Item } & \multirow{2}{*}{ Description } & \multicolumn{3}{|c|}{ Factor Loading } \\
\hline & & 1 & 2 & 3 \\
\hline PB1 & I am satisfied with my current pay. & & 0.876 & \\
\hline PB3 & I am satisfied with my most recent pay increment. & & 0.857 & \\
\hline PB43 & I am satisfied with the pay structure offered by the college. & & 0.819 & \\
\hline PB65 & I am paid fairly for my job with the current job responsibilities. & & 0.775 & \\
\hline WE3 & My office or my area of work is comfortable and safe. & & & 0.894 \\
\hline WE4 & The amenities such as closets etc. in my office are clean. & & & 0.825 \\
\hline TML1 & My superior encourages me to become a good team player. & 0.872 & & \\
\hline TML2 & My superior leads by example. & 0.857 & & \\
\hline TML3 & My superior considered my personal feelings. & 0.771 & & \\
\hline TML4 & My superior is aware and pay attention to my needs and concerns. & 0.798 & & \\
\hline TML5 & My superior communicates freely. & 0.824 & & \\
\hline TML6 & I make decision on how to perform my job task. & 0.741 & & \\
\hline & Eigenvalue & 6.133 & 1.870 & 1.214 \\
\hline & Percentage of Variance Explained (\%) & 35.906 & 25.622 & 15.282 \\
\hline & Cumulative Percentage $(\%)$ & 35.906 & 61.528 & 76.810 \\
\hline & Reliability Coefficient (Cronbach Alpha) & 0.922 & 0.897 & 0.789 \\
\hline
\end{tabular}

Table 2 indicates a single factor loading for job satisfaction that comprises 8 items. Factors loadings for the items were greater than 0.50 and ranging from 0.603 to 0.823 . As indicated in Table 2, the results showed that the value KMO/MSA is higher than 0.80 (i.e. 0.880) for job satisfaction. Next, Bartlett's test of Sphericity was found statistically significant at $\mathrm{p}<0.001$ and thus supporting the factorability of the correlation matrix. Percentage of variance explained for the items is 54.271 with Eigenvalue of 4.342. Both Table 1 and Table 2 were showing the extracted factors have greatest importance in factor analysis. Hence, the construct validity has been confirmed by the statistical analysis results.

Reliability test is carried out in this study after factor analysis. Reliability is tested by using Cronbach's Alpha. The value of Cronbach's Alpha is generally varied from zero to one. If the value is near to one, indicating that the strength of the variable's internal consistency is greater [33]. According to researchers [33], the acceptable value of Cronbach's Alpha is from 0.70 to 0.95 . A reliability coefficient which exceeds 0.70 is deemed acceptable [34]. The reliability coefficients (Cronbach's Alpha) for the independent variables (i.e. top management leadership, pay and benefits and work environment) were 0.922, 0.897 and 0.789 respectively (see Table 1); while the Cronbach's Alpha for the dependent variable (Job Satisfaction) was 0.871 (see Table 2). As suggested by researcher [34], the results confirmed the establishment of the constructs' reliability. 
Table 2. Factor analysis for job satisfaction

\begin{tabular}{clc}
\hline \multirow{2}{*}{ Item } & \multicolumn{1}{c}{ Description } & Factor Loading \\
& & 1 \\
\hline JS1 & I am satisfied with my job. & 0.810 \\
JS2 & I enjoy my work most of the days. & 0.784 \\
JS3 & The major satisfaction in my life comes from my job. & 0.603 \\
JS4 & My job description reflects what I really do. & 0.788 \\
JS5 & I get a feeling of accomplishment from my job. & 0.647 \\
JS6 & I feel valued by senior management. & 0.823 \\
JS7 & My immediate superior lets me know how I am doing. & 0.673 \\
JS8 & I get full credit for the work I do. & 0.735 \\
& Eigenvalue & 4.342 \\
& Percentage of Variance Explained (\%) & 54.271 \\
& Cumulative Percentage (\%) & 54.271 \\
& Reliability Coefficient (Cronbach Alpha) & 0.871 \\
\hline Note: KMO $=0.880$, Bartlett's test of Sphericity; Approx Chi-Square $=285.844 .12<0.001$.
\end{tabular}

\subsection{Correlation analysis}

Pearson correlation coefficient is an indicator used to determine the degree and the direction of correlation between two study variables; the closer the coefficients to an absolute value of 1 , the higher the degree of correlation [35]. Table 3 shows that top management leadership $(r=0.758, p<0.01)$ has the strongest correlation with job satisfaction, followed by pay and benefits $(r=0.556, p<0.01)$ and work environment $(\mathrm{r}=0.538, \mathrm{p}<0.01)$. The results show positive intercorrelations among the variables.

Table 3. Correlation between the independent variables and job satisfaction

\begin{tabular}{ccccc}
\hline & $(\mathrm{PB})$ & $(\mathrm{WE})$ & (TML) & (JS) \\
\hline Pay and Benefits (PB) & 1 & & & \\
Work Environment (WE) & $0.362^{* *}$ & 1 & & \\
Top Management Leadership (TML) & $0.495^{* *}$ & $0.465^{* *}$ & 1 & 1 \\
Job Satisfaction (JS) & $0.556^{* *}$ & $0.538^{* *}$ & $0.758^{* *}$ & 1 \\
\hline
\end{tabular}

**Correlation is significant at the 0.01 level (2-tailed)

\subsection{Multiple regression analysis}

To conduct hypothesis testing, we used multiple regression analysis which is appropriate for two or more predicting variables [36]. Table 4 shows the results of multiple regression analysis of the study variables. The value of the coefficient of determination $\left(\mathrm{R}^{2}=0.649\right)$ indicates that $64.9 \%$ of the variance of job satisfaction can be explained by the research model. The analysis shows that top management leadership $(\beta=0.563, p<0.001)$ has the strongest significant relationship with job satisfaction, followed by pay and benefits $(\beta=0.204, p<0.05)$ and work environment $(\beta=0.203, p<0.01)$. Therefore, hypothesis H1, H2 and H3 are accepted.

Table 4. Multiple regression analysis for the independent variables and job satisfaction

\begin{tabular}{|c|c|c|c|c|c|c|}
\hline \multirow{2}{*}{ Independent Variables } & \multicolumn{4}{|c|}{ Job Satisfaction } & \multirow{2}{*}{ Hypothesis } & \multirow{2}{*}{ Result } \\
\hline & Beta, $\beta$ & Sig. & $\mathrm{B}$ & Std. Error & & \\
\hline Pay and Benefits (PB) & $0.204^{*}$ & 0.011 & 0.141 & 0.054 & H1 & Accepted \\
\hline Work Environment (WE) & $0.203 * *$ & 0.010 & 0.142 & 0.054 & $\mathrm{H} 2$ & Accepted \\
\hline Top Management Leadership (TML) & $0.563 * * *$ & 0.000 & 0.448 & 0.066 & $\mathrm{H} 3$ & Accepted \\
\hline F value & \multicolumn{6}{|c|}{48.115} \\
\hline R Square & \multicolumn{6}{|c|}{0.649} \\
\hline
\end{tabular}

This research explored factors that influence job satisfaction among academic staffs in a private institution in Malaysia. The findings revealed that there are significant relationships between pay and benefits, work environment, top management leadership and the taget construct job satisfaction. The current level of job satisfaction among academic staffs was high $(\mathrm{M}=3.7896, \mathrm{SD}=0.5944)$. Although all predictors (i.e. pay and benefits, work environment and top management leadership) were significantly associated with job satisfaction $(\mathrm{p}<0.05)$, however, the beta values for pay and benefits, work environment and top management leadership were differed at $0.204,0.203$ and 0.563 respectively. Thus, the findings suggested that top management leadership remains the major determinant that influences job satisfaction. In this study, the finding showed that there is a significant positive relationship between pay and benefits and 
job satisfaction $(\beta=0.204, p<0.05)$. It explains that the higher the pay and benefits, the higher the job satisfaction of the academic staffs. This finding is consistent with the studies conducted by researchers $[9,10,37]$, where they discovered that pay and benefits were the most important contributor towards job satisfaction. Next, work environment was found to be significantly related to job satisfaction $(\beta=0.203, p<0.01)$. This result is similar to the studies of $[5,12]$ where it was mentioned that conducive work environment motivates academic staffs to achieve higher job satisfaction. Finally, top management leadership was found to have a significant positive relationship with job satisfaction $(\beta=0.563, p<0.001)$. This finding again was supported by researchers [38] where they concurred that top management leadership plays a significant role in improving academic staffs' job satisfaction. If superiors are having bad temper and lack of understanding, it will further deteriorate job dissatisfaction. In summary, this research provides important information to the management of the academic institution to find ways to increase job satisfaction level among its academic staffs. Pay and benefits, work environment and top management leadership are the areas that should be given extra attention if the management would like to produce quality academic staffs with greater job satisfaction.

\section{CONCLUSION}

This study has successfully identified significant factors that influence job satisfaction among the academic staffs in Malaysia. The findings of this study generate managerial actions that focus on pay and benefits, work environment and top management leadership to increase job satisfaction among the academic staffs. This reasearch is in tandem with the direction of the Malaysian Quality Evaluation System for Private Colleges (MyQUEST) to elevate the quality level of education and achieve six stars in the rating system.

This study has some limitations that need to be addressed in future research. First, the research context and findings were limited to one academic institution in Malaysia. Therefore, the results may not able to generalize for the entire education industry in the country. In future, researchers may consider increasing the population to cover more institutions in Malaysia. In addition, based on different theories that have been explained previously, there are other determinants such as mentorship, coaching, career planning and job rotation that may influence job satisfaction. Hence, it is suggested that more variables can be explored to predict job satisfaction in this research context.

\section{ACKNOWLEDGEMENTS}

The authors wish to thank the Malaysian Ministry of Education and Universiti Teknologi Malaysia (GUP Tier 2: 15J99) for providing financial support to publish this paper.

\section{REFERENCES}

[1] Aslan, A. S., Shaukat, M. Z., Ahmed, I., Shah, I. M., and Mahfar, M., "Job satisfactions of academics in Malaysian Public Universities," Procedia - Social and Behavioral Sciences, vol. 114, pp. 154-158, 2014.

[2] Naseem, I. and Salman, M., "Measuring the job satisfaction level of academic staff," Journal of Business \& Financial Affairs, vol. 4, no. 2, 2015.

[3] Awang, Z., Ahmad, J. H., and Zin, N.M., "Modelling job satisfaction and work commitment among lecturers: A case of UiTM Kelantan," Proceedings of the Regional Conference on Statistical Sciences, pp. 241-255, 2010.

[4] Saba, I., "Measuring the job satisfaction level of the academic staff in Bahawalpur Colleges," International Journal of Academic Research in Business and Social Sciences, vol. 1, no. 1, 2011.

[5] Umaru, R. I., and Ombugus, D. A., "Determinants of job satisfaction of colleges of education lecturers: A Study of Nasarawa State College of Education," Akwanga, vol. 2, no. 1, pp. 8-13, 2017.

[6] Chamundeswari, S., "Job satisfaction and performance of school teachers," International Journal of Academic Research in Business and Social Sciences, vol. 3, no. 5, pp. 420-428, 2013.

[7] Tessema, M. T., Ready, K. J., and Embaye, A. B., "The effects of employee recognition, pay, and benefits on job satisfaction: Cross country evidence," Journal of Business and Economics, vol. 4, no. 1, pp. 1-12, 2013.

[8] Klonoski, R., "Defining employee benefits: A managerial perspective," International Journal of Human Resource Studies, vol. 6, no. 2, 2016.

[9] Makena Muguongo, M., "Effects of compensation on job satisfaction among secondary school teachers in Maara Sub - County of Tharaka Nithi County, Kenya," Journal of Human Resource Management, vol. 3, no. 6, p. 47, 2015.

[10] Dulebohn, J. H. and Werling, S. E., "Compensation research past, present and future," Human Resource Management Review, vol. 7, no. 2, pp. 191-207, 2007.

[11] Linh, L. H., "Researching on factors affecting job satisfaction of lecturers in Universities of Ho Chi Minh City, Vietnam," American Journal of Educational Research, vol. 6, no. 7, pp. 1056-1062, 2018. 
[12] Shah, M. J., "Job satisfaction and motivation of teachers of public educational institutions," International Journal of Business and Social Science, vol. 3, no. 8, pp. 271-282, 2012.

[13] Hee, O.C., Cheng, T.Y., Yaw, C.C., Gee, W.V., Kamaludin, S.M., and Prabhagaran, J.R., "The influence of human resource management practices on career satisfaction: evidence from Malaysia," International Review of Management and Marketing, vol. 6, no. 3, pp. 517-521, 2016.

[14] Oludeyi, O. S., "A review of literature on work environment and work commitment: Implication for future research in Citadels of learning," Journal of Human Resource Management, vol. 18, no. 2, pp. 32-46, 2015.

[15] Abdul, P. and Awan, G,. "Impact of working environment on employee's productivity: A case study of Banks and Insurance Companies in Pakistan," European Journal of Business and Management, vol. 7, no. 1, pp. 329-346, 2015.

[16] Anastasiou, S. and Papakonstantinou, G., "Factors affecting job satisfaction, stress and work performance of secondary education teachers in Epirus, NW Greece," International Journal of Management in Education, vol. 8, no. 1, pp. 37, 2014.

[17] Naz, S., "Factors affecting teachers job satisfaction," Market Forces, vol. 12, no. 2, pp. 44-59, 2017.

[18] Ghani, J. A., and Khamis, N. K., "Role of senior management in TQM implementation in the Malaysian small and medium enterprises," pp. 15-20, 2008.

[19] Glamuzina, M., "Levels of leadership development and top management's effectiveness: Is there a clear-cut relationship?" Management, vol. 20, pp. 89-132, 2015.

[20] Hee, O.C., Ibrahim, R., Kowang, T.O., and Fei, G.C., "Employee engagement as a mediator between transformational leadership and employee performance," Asian Journal of Scientific Research, vol. 11, no. 3, pp. 441-448, 2018.

[21] You, S., Kim, A. Y., and Lim, S. A., "Job satisfaction among secondary teachers in Korea: Effects of teachers' sense of efficacy and school culture," Educational Management Administration and Leadership, vol. 45, no. 2, pp. 284-297, 2017.

[22] Dasgupta, P. R., "Volatility of workload on employee performance and significance of motivation: IT sector," Science Journal of Business and Management, vol. 1, no. 1, pp. 1-7, 2013.

[23] Saad, S., Shah, H., Jaffari, A. R., Aziz, J., Ejaz, W., Ul-haq, I., and Raza, S. N., "Workload and performance of employees," Interdisciplinary Journal Of Contemporary Research In Business, vol. 3, no. 5, pp. 256-267, 2011.

[24] Lam, B. H., and Yan, H. F., "Beginning teachers' job satisfaction: the impact of school-based factors," teacher development, vol. 15, no. 3, pp. 333-348, 2011.

[25] Anghelache, V., "Factors which determine the level of job satisfaction for Kindergarten teachers. Preliminary study," Procedia- Social and Behavioral Sciences, vol. 127, pp. 47-52, 2014.

[26] Krejcie, R.V. and Morgan, D.W., "Determining sample size for research activities," Educational and Psychological Measurement, vol. 30, pp. 607-610, 1970.

[27] Lottes, D. and Brown, D., "Western Kentucky University Staff satisfaction survey," 2008. Retrieved on Mar 23, 2019. [Online]. Available: https://www.wku.edu/staffcouncil/documents/staffsatisfactionreport2008.pdf

[28] City, D. Q., "Job satisfaction level of k to 12 teachers utilizing multiple statistical tools," Asia Pacific Journal of Contemporary Education and Communication Technology, vol. 3, no. 1, pp. 1-11, 2017.

[29] Munisamy, S. "Identifying factors that influences job performance amongst employees in oil palm plantation," 2013. [Online]. Available: http://library.oum.edu.my/repository/979/1/library-document-979.pdf

[30] Asghar, S. and Oino, I., "Leadership styles and job satisfaction," 2017. Retrieved on March 23, 2019. [Online]. Available: https://mpra.ub.uni-muenchen.de/91137/1/MPRA_paper_91137.pdf

[31] Al-Rubaish, A. M., Rahim, S.I., Abumadini, M.S., and Wosornu, L., "Academic job satisfaction questionnaire: Construction and validation in Saudi Arabia," Journal of Family and Community Medicine, vol. 18, no. 1, pp. 1-7, 2011.

[32] Hutcheson, G. and Sofroniou, N., The multivariate social scientist, London: Sage, 1999.

[33] Tavakol, M. and Dennick, R., "Making sense of cronbach's alpha," International Journal of Medical Education, vol. 2, pp. 53-55, 2011.

[34] Andrew, G., "Analysing data using SPSS: A practical guide for those unfortunate enough to have to actually do it," Sheffield Hallam University, pp. 1-94, 2008.

[35] Arkkelin, D., "Using SPSS to understand research and data analysis," Psychology Curricular Materials, p. 194, 2014. [Online]. Available: http://citeseerx.ist.psu.edu/viewdoc/download?doi=10.1.1.139.2050\&rep=rep1\&type= pdf

[36] Statistics Solutions, "Conduct and interpret a multiple linear regression," pp. 1-5, 2016. Retrieved on Mar 2019. [Online]. Available: http://www.statisticssolutions.com/multiple-linear-regression/

[37] Fessehatsion, P. W. and Bahta, D. T., "Factors affecting academic job satisfaction in the public institutions of higher education, eritrea," Research on Humanities and Social Sciences, vol. 6, no. 11, pp. 1-6, 2016.

[38] You, S., Kim, A. Y., and Lim, S. A., "Job satisfaction among secondary teachers in Korea: Effects of teachers' sense of efficacy and school culture," Educational Management Administration and Leadership, vol. 45, no. 2, pp. 284-297, 2017. 